\title{
Definitions of Self and Other in and Through Literary Communication
}

\author{
Manfred Malzahn \\ United Arab Emirates University, Al-Ain, United Arab Emirates
}

\begin{abstract}
This paper investigates the dual nature of literary communication as representing fictional identities and interactions, while at the same time, constituting definitions of self and other in the communication between real authors and readers. The main theoretical framework for this paper's argument is the theory of communication developed and presented by Watzlawick, Bavelas, and Jackson (1967), in their groundbreaking study "Pragmatics of Human Communication". In the following, their theory of communication is used as a means of situating literature as an interface between the poles of cognition and construction: a field where definitions of identity can be posited and mediated in the interaction between "the only sub-universe...within which we can establish communication with our fellow-men” (Embree, 1998, p. 51), and finite provinces of meaning created by the literary imagination.
\end{abstract}

Keywords: literature, communication, self, other, content, relationship, digital, analogic

\section{The Nature of Literary Communication}

Literature has variously been conceived as a vehicle of self-expression, self-assertion, self-discovery, or self-disguise. In the view of writers, such as William Wordsworth (1994a) or Walt Whitman (1900), the self has been not only the supreme source, but also a proper subject of poetic creation. Others, such as John Keats (1817) or T. S. Eliot (1921), have advocated authorial self-effacement or the "depersonalization” (Eliot, 1921) of poetry.

While these different principles may seem equally valid, they may not be equally viable. If poetic practice is measured against the authors' own criteria, we are likely to find more congruence in the oeuvres of self-avowed self-seekers. Wordsworth's (1994, p. 877) intention "To speak, what I myself have known and felt” was obviously easier to realize than other writers' efforts to keep their own selves out of their texts. A major impediment to the success of such vanishing acts lies on the mindset of such readers who deliberately seek to spot the person through the persona, or who are at least aware that, however, impersonal art may appear, it was always produced by individual human beings and is bound to reflect this in some ways or forms.

The existence of real authors and readers who produce and respond to textual artifacts marks literature as a species of communication; and if it is, it must be possible to define the special nature of literary communication in terms of models that represent communication in general. This has of course been attempted, although with varied success. Jakobson's (1960) diagnosis of the poetic function, for instance, as a focus on form brought about "by the 'non-canonical' operation of linguistic rules" (Widdowson, 2008, p. 505), applies to a quality that

Manfred Malzahn, Ph.D., professor, Faculty of Humanities and Social Sciences, United Arab Emirates University. 
can occur in both literary and non-literary communication, whereas the fundamental difference between those two clearly lies on the fictional or non-fictional nature of the respective subject matter.

It is the coexistence between the real and the imagined that accounts for the complexity of literary communication. If even the aspect of literary creativity "has to be accounted for in general pragmatic terms" (Widdowson), then surely the whole process including the perception and effect of literary artefacts necessitates a pragmatic approach. One such approach that the author thinks is particularly apt to help elucidate the issues involved, has been put forward in the study "Pragmatics of Human Communication" (Watzlawick, Bavelas, \& Jackson, 1967), which has a psychological and psychiatric focus and whose range of examples include fictional ones.

Watzlawick et al. (1967) have claimed that there are two distinct aspects to every communication, namely, the content and the relationship aspect. What is transported at the content level is explicit or digital information, while, at the relationship level, the same communicational act carries implicit or analogic definitions of self and other, which will then prompt either a confirmation, a rejection or else a disconfirmation on the part of the receiver.

\section{The Rhetoric of Failure and the Failure of Rhetoric: John Donne's “The Flea”}

As a means of illustration, consider John Donne's (1996) poem “The Flea”, in which the speaker points out a flea on the addressee's skin and then presents an argument based on the ludicrous contention that the mingling of his and the addressee's blood in the insect has already brought about the union that he desires and she rejects. While after the deictic opening, the informational content dwindles to zero, the offered definition of self and other as a couple of lovers waxes ever more urgent or desperate. The addressee's reported killing of the flea is a purely analogic rejection of the relationship offer. The analogic aspect of the ensuing rhetorical coda is a rejection of the addressee's rejection and a renewal of the initial relationship offer, which is, however undercut by the digital invalidation of the speaker's previous argument, in a self-defeating move that brands him even more clearly as "a sophist who cannot be taken at his word” (Malzahn, 2003, p. 60).

The author/reader communication transacted through the poem is of course simultaneous with the speaker/addressee communication recorded in the poem (see Table 1). This means that each successive part of the speaker's statement has two times two aspects, as a part of two different communications.

Table 1

Content and Relationship Aspects in Literary Communication

\begin{tabular}{|l|l|}
\hline I: Speaker to addressee & II: Author to reader \\
\hline Content I & Content II \\
\hline Relationship I & Relationship II \\
\hline
\end{tabular}

While we can expect striking differences to exist between the two relationship aspects, there is also a significant disparity between Content I and Content II, for the latter includes not only information given by the speaker to the addressee, but also information about the speaker and the situation given by author to reader. The opening words of the poem, for example, tell the addressee that there is a flea on her skin. But, they moreover tell the reader that the speaker is placed close enough to the addressee to perceive the small insect. The subsequent information that the flea sprang from him to her reinforces the impression that at least some degree of intimacy exists between the characters. These statements bracket and contextualize the speaker's mention of 
the lady's denial. Similarly, the mention of her refusal conveys a new fact only to the reader and is thus of informational value only in Content II, where anything that is said can add another facet to the reader's picture of the speaker, the addressee and the circumstances.

While the distinctions between Content I and Content II are noteworthy, the definitions of self, other and relationship that were offered by the author to the reader of "The Flea" differ more blatantly from those offered by the speaker to the addressee. To begin with, Donne’s contemporary readers were more likely to be male than female, and hence the much-quoted criticism that in lieu of genuinely emotional love poetry, Donne's work has one that merely "perplexes the minds of the fair sex with nice speculations of philosophy" (Dryden, 1986, p. 106), and bespoke first and foremost a confusion between the levels of communication.

"The Flea”, in particular, did not even feature philosophy, but instead, rhetorical fireworks of absurd brilliance or brilliant absurdity that appeared as both the speaker and the author's invention: The difference being that the manner chosen to impress the reader was to show the failure of the speaker's rhetoric to impress the addressee. The definition of self Donne put forward, thus, seems to have been that of a man of the world who was at once clever with words and willing to expose or satirize the limited benefits of verbal cleverness. The offered definition of the other seems to have been that of a person open-minded and witty enough to appreciate such a man and stance. Seen in this light and in the terms of Watzlawick et al. (1967), it would appear that John Dryden's (1986) comment was a rejection of the proposed definitions and the proposed coterie or complicity with the fellow—author Donne.

If the method of Watzlawick et al. (1967) illuminated the communicational impact of poetry of which primary aim is to impress rather than express and fictitious selves are quite distinct from the authorial self, it is not guaranteed to prove equally fruitful with regard to lyric poems that appear to lay open the author's thoughts and feelings. One classic case in point will serve for a token analysis that shows the communicational complexities of the genre: the penultimate poem in the sequence of Elizabeth Barrett Browning's (1998) "Sonnets from the Portuguese". It contains a straightforward declaration of affection that begins with the line "How do I love thee? Let me count the ways".

The researcher has yet to come across any reasonable doubt of this poem's autobiographical genesis and reference, but a frequent problem with autobiographical readings is that they tend to divert attention from the abovementioned multi-functionality of literary utterances. If we apply the terminology of Watzlawick et al. (1967) as a tool to even out this deficit, we are bound to first of all note the speaker's attempt to verbalize a profound and complex emotion, as being an attempt to convey an analogic message in digital language. Watzlawick et al. (1967) have defined the difference between the two codes as follows:

Human beings communicate both digitally and analogically. Digital language has a highly complex and powerful logical syntax but lacks adequate semantics in the field of relationship, while analogic language possesses the semantics but has no adequate syntax for the unambiguous definition of the nature of relationships. (pp. 66-67)

Translations of this kind are consequently bound to problematic, but at the same time, they are inevitable in the process of communication that Lakoff and Johnson (1980) have described as crucial to self-knowledge. These authors have claimed that "The skills for mutual understanding are necessary even to approach self-understanding” (Lakoff \& Johnson, 1980, p. 232), and further that innovative language use is not merely an expression, but a means of self-cognition, achieved in the attempt to communicate one's emotions and verbalize the nature of one's relationships with others. In Lakoff and Johnson's (1980) view, the highest level 
of individuality is both created and manifested by "engaging in an unending process of viewing your life through new alternative metaphors” (Lakoff \& Johnson, 1980, p. 233).

In this process, an actual or imagined addressee is certainly a useful, and perhaps even a necessary catalyst. Speakers in lyric poems are often visualized as being alone. The isolation or aloofness of the speaking voice can be seen as conducive to depth of thought, authenticity of feeling, or careful choice of expression. But, while no listeners are present, the addressees tend to be more or less palpable as a focus for a lyric voice that does not ring out into a void, but communicates. Instead of being pure monologues, love lyrics are particularly apt to reveal a dialogic character, if looked at as communications between a lover and a beloved. Browning's (1998) speaker, for instance, is answering a question that was either consciously raised or unconsciously prompted by the addressee. In either case, the speaker was made to feel that a confirmation of the relationship was called for.

The manner in which this confirmation is given stands in marked contrast to the brevity and simplicity of the initial question. The force and hyperbolic scope of the rhetoric produced by Browning's speaker are comparable to that produced by the speaker in "The Flea", although the two characters range at opposite ends of the sincerity scale, and although the metaphors coined by Donne's (1996) speaker are not means of (self-) cognition but of deception, as if he were in an anti-Gricean dystopia. The potential problem facing the implied addressee in Browning's poem, however, is that while he can hardly refuse the declaration of love for which he has asked, it comes in so complete and categorical a form that it forestalls any chance of him asking for anything more. The resulting predicament seems greater than that of the addressee in "The Flea", who after all has and uses the option of rejection, in the kind of move Watzlawick et al. (1967) have termed a symmetrical, as opposed to a complementary one. Their definition of this dichotomy reads as follows (Watzlawick et al., 1967, p. 27), "All communicational interchanges are either symmetrical or complementary, depending on whether they are based on equality or difference".

If these are indeed the only two options, they must both be classed as "normal", for otherwise, there would hardly be any room for choice within the bounds of normality. However, according to Watzlawick et al. (1967), both carry the seeds of pathological development, for complementary interaction may become too rigid and symmetrical interaction escalate too far.

In the case of Browning's (1998) speaker and addressee, rigidity would include repetition, since the communicational sequence seems to have reached a culmination that is at the same time a dead end. The addressee's perceived need for a confirmation of the relationship has been answered with an "embarras de richesses”. This metaphoric enlargement of love was hardly less lavish than that of the flea in Donne's (1996) poem, and Browning's (1998) speaker topped her hyperboles with a further imaginative extension of her love into the afterlife. There is clearly no room for any further development in this direction, nor for symmetrical escalation of the "I love you even more than you love me” type. If we read Browning's (1998) "Sonnet 44" as a continuation of the communicational sequence after the final flourish of "Sonnet 43 ", what we consequently see is an anticlimactic move.

\section{From Speaker/Addressee to Author/Reader Communication}

But what is the reader to make of this? First of all, we must distinguish between one person who could have been forgiven for reading the poem as a non-fictional and private utterance meant exclusively for him, and all other possible or actual readers who could hardly presume that they were the person the author had in mind. By means of identification with the speaker or, if the abovementioned predicament is not recognised, with the 
addressee, the reader may construct a daydream fantasy of the type identified by Freud, in which "Past, present and future are strung together, as it were, on the thread of the wish that runs through them” (Freud, 1907, p. 439).

In a less naïve and more literary sense, however, the reader may respond to the self-definition the author offers him/her, as one that is necessarily different from the self-definition offered to the addressee. At the same time, as Browning's (1998) speaker says to the addressee "See me as a woman who loves you perfectly", the author says to the reader, "See me as a person who has known perfect love". The corresponding definitions of other simultaneously transmitted are "I see you as the man who will appreciate and requite my perfect love" on the level of speaker/addressee communication and "I see you as a person who knows perfect love when you see it" on the level of author/reader communication. The proposed analogic understanding of author and reader is what phenomenological criticism calls a "mutual tuning-in relationship-the establishment of the intersubjective basis of communication” (McDuffie, 1998, pp. 89-90).

The reading of poetry is a process that relies even more heavily on such tuning-in than that does literary communication in other genres. Novelists or dramatists are looked upon by many members of their audiences as chefs are by customers in restaurants: One can savour their dishes without perceiving a personal bond with them, unless one is a gourmet served by a master. Poets are much more frequently thought of to be composers of music. It is far less likely that a personal relationship with them is neither sought nor felt by their readers. While author/reader communication also exists in and through fiction and drama, its poetic version is most easily recognisable as having an analogic or relationship aspect. Self-cognition of the reader may progress by acceptance or rejection of self-definitions proposed as definitions of other by poets who appeal to readers with a certain type of sensibility. As readers, we may explore affinities with certain poets in our own "search for appropriate personal metaphors that make sense of our lives” (Lakoff \& Johnson, 1980, p. 233).

\section{Poetic Self-definitions and Definitions of Author/Reader Relationship}

A constant, if often underrated or underplayed element at the heart of the poet/reader relationship, is the self-definition of the poet as poet, in other words, as one who has a particular way with words. Even the most modest poetic effort contains the injunction to the reader, "See me as a person who has a poetic gift", while saying, "I see you as someone who is perceptive enough to see and value this gift in me". Poetic communication, thus, relies on a relationship that rests on a fundamental complementarity of appreciation or admiration, but that can lead up to a semblance of symmetricality.

The poet as author is initially in "What has been variously described as the superior, primary, or 'one-up' position” (Watzlawick et al., 1967, p. 69), but the reader's complementary responses can add up to a perceived near-equality, in partial identification with or appropriation of the poet's sense of self. This would be difficult to achieve in a face-to-face situation and it is the absence of the poet that facilitates the piecemeal incorporation of his/her poetic sensibility into the reader's self-definition. The adoption of a Wordsworthian sense of identity may come as the cumulative effect of a repeated recognition of one's own sensations, thoughts and emotions in Wordsworth's poems. The ultimate possible result will be a perception of symmetricality, while each "This is exactly how I feel" was obviously a complementary response to the authorial injunction "Feel as I feel", or "Share my experience".

The latter phrase is worth a closer look. In contemporary parlance and especially in North American usage, to share an experience seems to mean little more than to tell others about an experience that one has had. The 
euphemistic potential of the cliché is evident, for having been told about something does not necessarily mean that one has had any kind of share in it. If the researcher shares an apple with someone, the person with whom the researcher shares will taste the same fruit, if the researcher tells this person about an apple in his grandfather's garden that he ate as a child, his story may at best evoke memories of a similar experience. By making the researcher's account vivid enough, however, he may bring it to attain that quality which Joseph Conrad (1898) saw as the main characteristic of art: its power to evoke the existential truth of a particular life-sensation, "the stress and passion within the core of each convincing moment" (Conrad, 1898), and thus to counteract not only the remorseless passage of time, but also likewise the existential isolation of individual human beings.

The relationship Conrad (1898) offered to the his public appeared clearly symmetrical, with the author saying to the reader, "See me as one who can make you see imaginatively what you do not see physically" and "See yourself as one who is receptive and responsive to a master artist's suggestions". If Donne's "Songs and Sonets" offered the intended reader membership in a community of wit to which access could be gained through deciphering intricate verbal puzzles, and if Elizabeth Barrett Browning's (1998) "Sonnets from the Portuguese" offered the intended reader membership in a community of sensibility to which access could be gained through profound fellow-feeling, Conrad's (1898) fiction invited the intended reader to join a community of awareness to which access could be gained through active or passive involvement in art's struggle against the fundamental incommunicability of any individual life-experience.

The latter effort is of course paradoxical and so is the aspiration of fiction to embody truth, even more so, if this is truth be not of a philosophical or metaphysical, but of an existential kind. After all, any reader must eventually return from the imagined to his/her own paramount reality, after a temporary sojourn in "a finite province of meaning that transcends the autobiographical situation of the beholder” (McDuffie, 1998, p. 90). What remains are the memories of stories and characters or selves that enter the store of characters we have never met, but heard about a store where fact and fiction coexist and sometimes intertwine. If we liked the work we have read, we are moreover likely to remember the relationship with author as one with a person who gave us some degree of pleasure: "The purely formal—that is, aesthetic —yield of pleasure which he offers us in the presentation of his phantasies” (Freud, 1995, p. 443).

From Freud's (1995) perspective, the function of this aesthetic pleasure is strictly subordinate: "an incentive bonus, or a fore-pleasure, ... which is offered to us so as to make possible the release of still greater pleasure arising from deeper psychical sources” (p. 443) ${ }^{1}$. In the 1907 paper quoted here, this greater pleasure itself is in turn divided into two possible stages: First, vicarious wish-fulfillment brought about in the identification of the reader with hero-figures who represents "His Majesty the Ego" (Freud, 1995, p. 441); and second, liberation of the reader to pursue his/her own daydreams "without self-reproach or shame" (Freud, 1995, p. 443). To put this in the terms of Watzlawick et al. (1967), Freud (1995) has suggested a successive logic in the analogic formation of a relationship between readers and authors of fiction: First, a complementary stage when the reader lets the attribution of his/her sympathies be guided by the author's explicit or implicit directions; and Second, a symmetrical stage when the reader becomes the creator of his/her own fantasies.

The second of these stages is certainly of communicational interest inasmuch, as it constitutes observable responses, but lies outside the reading proper. But the first, the phase where the reader's sympathies are steered

\footnotetext{
1 The original German in the paper "Der Dichter und das Phantasieren” is: “eine Verlockungsprämie oder eine Vorlust”. This might also be translated as "a seductive bonus or a pre-lust".
} 
along by the author, is worthy of even greater note and critical comment. Since it is a hallmark of great literary art to present a differentiated picture of human character, motivation and behavior, identification with the hero of a novel can hardly be uniformly easy or entirely problem-free. If it is not, problems or ambivalences will act as reminders of the existence of an author who has made life difficult for the protagonist and the reader alike.

Take Thomas Hardy's (2007) Mayor of Casterbridge as an example. The story begins with an episode in which the central character Michael Henchard appears in the worst possible light: selling his wife in a drunken distemper to a stranger in the crowd at a country fair. By choosing this opening, Hardy has set a challenge to the reader: The offered relationship is highly symmetrical and the authorial self-definition a gauntlet bearing the motto, "See me as one who will test your willingness to believe that people can change for the better". The reader who takes up this gauntlet will at first feel vindicated by seeing a reformed Henchard, sober and respectable, but having enabled or encouraged readers' identification to a degree that seemed all but precluded after the chosen start, Hardy brought the novel to an ending that is presented as the logical and virtually inevitable consequence of character and circumstance, with a touch of coincidence thrown in for good measure.

The author/reader communication instigated here can be likened to a double bind, a pathological pattern which has three key ingredients as defined by Watzlawick et al. (1967). First, it operates within "an intense relationship that has a high degree of physical and/or psychological survival value” (Watzlawick et al., 1967, p. 212) for at least one of the communicants involved. Second, it involves a message that contains a contradictory injunction that "must be disobeyed to be obeyed" (Watzlawick et al., 1967, p. 212) or that has an undecidable meaning. In both cases, the message: "(1) asserts something; (2) asserts something about its own assertion; and (3) is these two assertions that are mutually exclusive" (p. 212). Third, "The recipient of the message is prevented from stepping outside the frame set by this message, either by meta-communicating (commenting) about it or withdrawing” (p. 212).

In literary communication, the relationship in question is of course the one between author and reader, which is ostensibly very different from the vital face-to-face systems that Watzlawick et al. (1967) have diagnosed in families or marriages. We may nevertheless take for granted that at least for a certain kind of reader, reading literature is a serious activity. Literary communication plays an important part in many people's ongoing self-formation or self-confirmation, while reader response is self-evidently crucial for any author with artistic or professional-commercial ambition.

The intended public for The Mayor of Casterbridge in Late Victorian Britain belonged to a culture where the key values of earnestness, responsibility and propriety were under attack from various quarters, and many readers were still looking to literary authors and works for wisdom, guidance, or moral exemplars. The orthodox blueprint for a novel following the fortunes of a hero over a long period of time was the Bildungsroman: the novel of education that charted the hero's moral progress and social integration. For a reader coming to a book from such an angle, the expected injunction was "taking a sympathetic interest in the hero of this novel". The opening episode of The Mayor of Casterbridge, however, seemed to carry the injunction to dislike Henchard, an injunction that had to be disobeyed in order to fulfill the sine-qua-non condition for a continuation of the literary communication.

In the context of this communication, a discontinuation of the reading can be seen as what Watzlawick et al. (1967, p. 86) call a "disconfirmation”. If at the analogic level, Hardy’s (2007) proposal to the reader was, "Seeing me as an English novelist of the first order", then negative criticism was a rejection of this proposal. Watzlawick et al. (1967) have distinguished disconfirmation from rejection as follows: "While rejection 
amounts to the message 'You are wrong', disconfirmation says in fact 'You do not exist'” (p. 86). If a writer reads negative criticism, he/she is at least being noticed; if there are no reviews and low sales, the targeted audience is sending a message of disconfirmation to the author. The literary audience is of course free to thus ignore the existence of any particular writer, with one interesting exception, which is the use of literary works in educational contexts. Here, the third feature of the double bind is most clearly given: the inability of the message recipient to step outside of the communicational framework. It may thus be only in education that literary double binds can generate full-blown communicational pathologies.

If the researcher has moved rather rapidly from the function of literature as a help in the development and refinement of one's individual self to potential pathologies in literary communication, he should put the latter into perspective by pointing out a potentially positive result. If an author observes pathological patterns of communication in reality and then creates fictional representations of such patterns, readers may in turn observe those patterns in fiction, and then diagnose them in their own reality. If the author/reader communication itself has pathological traits, then the recognition of these traits by the reader can set a template for the reader's emancipation or liberation from non-fictional traps or constraints. While fiction and reality may be kept apart in the reading process, this process itself is both a part of the individual reader's reality and a means of expanding that reality through imaginative awareness of others, and ultimately through meta-communicational awareness of what Schutz (as cited in Knoblauch, 1999) has called a fundamental "paradox of communication", occasioned by the simultaneous necessity and impossibility "to catch the world of inner experience in the net of words” (as cited in Knoblauch, 1999, p. 17).

The researcher believes that literature can help to generate a critical awareness of this and other paradoxes, and that wanting literature to do so is both more realistic and more sensible than expecting it to bring about mystic unions or transcendental epiphanies, let alone to transport moral lessons. If literature is to serve as a vehicle of self-cognition, then the prime targets of cognition in literary communication should be the metaphors and narratives used in the fictional constructions of other selves, and the manner in which these constructions are achieved in a process of communication that may appear indirect and irreversible at first sight, but that closer analysis reveals to be more immediate and less monodirectional than it seems.

\section{Assumptions and Subversions of Literary Authority}

The congenial reader of literature should tune into the artist's frequency, but regard him/her as a normal human being with ordinary, and sometimes, even dubious or devious motivations. Uncritical acceptance of authorial self-definitions can hardly lead to a critical appreciation of art, and the ultimate task of a critical reader is tantamount to the function of the critic that has been postulated by D. H. Lawrence (1923, Ch. 1), namely, "to save the tale from the artist who created it". To facilitate a critical distance that helps us readers to avoid the danger of modeling our sense of self too readily on fictional selves, or of accepting authorial relationship offers and proposed definitions of self and other too unquestioningly, we may look at instances when authors have intentionally or unintentionally betrayed their weaknesses, inconsistencies, or vanities.

A classic example from the Elizabethan age is Sonnet number 75 from Edmund Spenser's (1966) "Amoretti", in which the poet-speaker's boast of his power to make his lady companion's name immortal stands in ironic contrast to the blatant absence of any such name from the poem that records this boast. If the speaker's injunction to the addressee is "See me as one who can make you famous long after your death", then the authorial injunction to the reader could well be phrased as "See me as a poet who is well aware of the 
egocentric tendencies poets have”. The fact that this sonnet is still read centuries after it was written is living proof of poetry's power to outlast the poet, but this is thrown into ironic relief by the fact that the only name the sonnet eternalises is not one that it contains, but one that accompanies it in print that of the author Spenser.

We can observe a similar irony in William Wordsworth's (1994b) poem “The Tables Turned”, in which the speaker exhorts the addressee to quit looking for wisdom and truth in books, and instead to go out and learn directly from Nature. If we equate addressee with reader, there is another variant of the double bind here, for the opening line "Up! Up! My Friends, and quit your books" should be obeyed, then the reading stops right there, and the reader will not benefit from the advice offered in the following 31 lines. In order to play the game, the reader thus has to disobey the injunction, or to assume that he/she is listening to an imagined speaker talking to an imagined addressee showing a comparable degree of reluctance to do as told. If the speaker's injunction to the addressee is "See me as one who can guide you to the source of natural wisdom", then the authorial injunction to the reader could well be phrased as "See me as a writer of books who warns against trusting any advice given in print”.

The fault lines shown here cut across categories: fictional and non-fictional realities and characters, content and relationship aspects of communication. What transpires is a picture of literature as a field where identities are examined and negotiated in communicational contexts, where texts serve as a means not only of expressing or manifesting, but of constructing and questioning definitions of self. Watzlawick et al. (1967) have shown how the scrutiny of literary texts can enrich psychological and psychiatric theory and practice. It is up to literary scholars to see to what extent the method of Watzlawick et al. (1967) could inform the study of literature criticism. In an age of interdisciplinarity, it is astonishing to find that literary criticism and theory have yet to tap the full potential of their theory of communication.

\section{References}

Browning, E. B. (1998). Sonnets from the Portuguese. Retrieved December 4, 2009, from http://www3.amherst.edu/ rjyanco94/ literature/elizabethbarrettbrowning/poems/sonnetsfromtheportuguese/howdoilovetheeletmecounttheways.html

Conrad, J. (1898). Preface. In The nigger of the narcissus. Retrieved December 4, 2008, from http://www.classicauthors.net/ conrad/Narcissus/Narcissus1.html

Donne, J. (1996). The flea. In The Norton anthology of poetry. Retrieved December 19, 2011, from http://www.poetryfoundation. org/poem/175764

Dryden, J. (1986). A discourse concerning the original and progress of satire. In A. L. Clements (Ed.), John Donne’s poetry (p. 106). New York: Norton.

Eliot, T. S. (1921). Tradition and the individual talent. In The sacred wood: Essays on poetry and criticism. Retrieved December 2, 2008, from http://www2.bartleby.com/200/sw4.html

Embree, L. (1998). A construction of Alfred Schutz's “sociological aspect of literature”. In L. Embree (Ed.), Alfred Schutz's “sociological aspect of literature”: Construction and complementary essays (pp. 3-71). Dordrecht, Boston \& London: Kluwer.

Freud, S. (1995). Creative writers and day-dreaming. In P. Gay (Ed.), The Freud reader (pp. 436-443). London: Vintage.

Hardy, T. (2007). The mayor of Casterbridge. Retrieved December 4, 2008, from http://www.gutenberg.org/files/143/143-h/ 143-h.htm

Jakobson, R. (1960). T. Sebeok (Ed.), Style in language. New York: Wiley.

Keats, J. (1817). Letter of 21 Dec. 1817, to G. \& T. Keats. In R. Selden (Ed.), The theory of criticism from Plato to the present (p. 306). London \& New York: Longman.

Knoblauch, H. (1999). Metaphors, transcendence and indirect communication. In L. Boeve, K. Frayaerts, \& J. Francis (Eds.), Metaphor and God-talk (pp. 75-94). Berne: Peter Lang. 
Lakoff, G., \& Johnson, M. (1980). Metaphors we live by. Chicago \& London: Chicago University Press.

Lawrence, D. H. (1923). The spirit of place. In Studies in classic American literature. Retrieved December 5, 2008, from http://xroads.virginia.edu/ HYPER/LAWRENCE/dhlch01.htm

Malzahn, M. (2003). The flea, the sun, and the critic: A communicational approach to john Donne's poetry. Symbolism: An International Annual of Critical Aesthetics, 3, 53-70. New York: AMS Press.

McDuffie, M. (1998). Literature, music, and the mutual tuning-in relationship. In L. Embree (Ed.), Alfred Schutz's "Sociological aspect of literature”: Construction and complementary essays (pp. 89-111). Dordrecht, Boston \& London: Kluwer.

Spenser, E. (1966). Amoretti. In Amoretti and epithalamion. Menston: Scolar Press. Retrieved December 19, 2011, from http://rpo.library.utoronto.ca/poem/1966.html

Watzlawick, P., Bavelas, J. B., \& Jackson, D. D. (1967). Pragmatics of human communication. New York: Norton.

Whitman, W. (1900). Leaves of grass. Retrieved December 19, 2011, from http://www.bartleby.com/142/14.html

Widdowson, H. G. (2008). Language creativity and the poetic function: A response to Swann and Maybin. Applied Linguistics, 29(3). Retrieved December 3, 2008, from http://applij.oxfordjournals.org/cgi/content/full/amn027

Wordsworth, W. (1994a). The prelude; or, growth of a poet's mind. In The collected poems of William Wordsworth (pp. 750-892). Ware: Wordsworth Editions.

Wordsworth, W. (1994b). The tables turned. In The collected poems of William Wordsworth (pp. 573-574). Ware: Wordsworth Editions. 